\title{
Modern slavery in the post-1994 South Africa? A critical ethical analysis of the National Development Plan promises for unemployment in South Africa
}

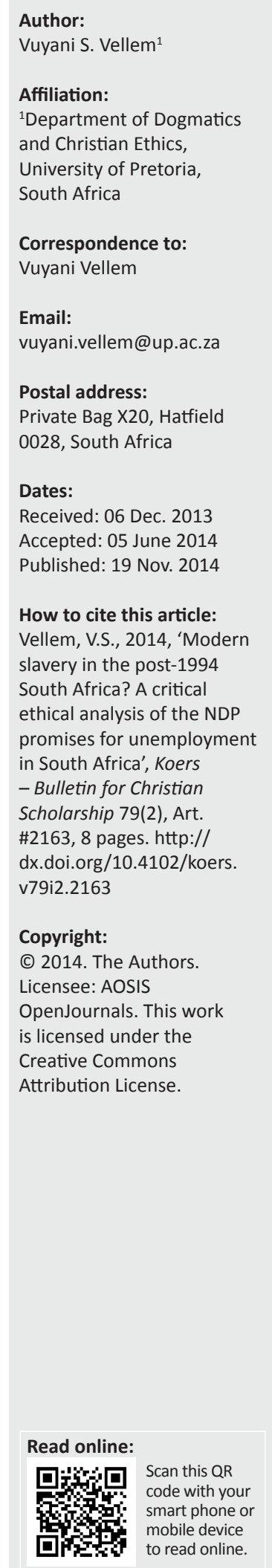

In African ethics, work is not work if it is not related to God or gods. Work, or umsebenzi, is for God or gods ultimately; work without God is the definition of slavery in my interpretation of the African ethical value system. If one succeeds from that understanding to define what slavery is, then God-lessness in work might imply the need for us to search for the gods of modernity post-1994 that have dethroned God, if they have not disentangled work from God. This article looks at the problem of unemployment by analysing the National Development Plan (NDP) and in particular the solutions proposed in relation to unemployment in South Africa. The article examines the language and grammar of the NDP to evaluate its response to the violent history of cheap, docile and migratory labour in South Africa.

Moderne slawerny in die post-1994 Suid-Afrika? 'n Kritiese en etiese analise van die nasionale Ontwikkelingsplan se beloftes aangaande werkloosheid in Suid-Afrika. In Afrika-etiek word die idee van 'werk' aan God of gode gekoppel. Werk, of umsebenzi, is uiteindelik vir God of gode; volgens my interpretasie van die Afrika-etiese waardestelsel is werk sonder God gelykstaande aan slawerny. Met so ' $n$ verstaan van slawerny kan goddeloosheid in werk impliseer dat ons post-1994 na die gode van moderniteit wat God onttroon het, indien nie werk van God ontkoppel het nie, soek. Hierdie artikel kyk na die probleem van werkloosheid deur die Nasionale Ontwikkelingsplan en in die besonder die voorgestelde oplossings vir werkloosheid in Suid-Afrika te analiseer. Die artikel ondersoek en evalueer die taal en grammatika van die NOP as respons op die gewelddadige geskiedenis van goedkoop en gewillige trekarbeid in Suid-Afrika.

\section{Introduction}

What types of jobs are promised by the National Development Plan (NDP)? Are they six million decent jobs? This paper subjects the NDP to a hermeneutic of suspicion. The question is whether the NDP can provide a solution to cheap labour - 'modern slavery' - my chosen term to designate cheap labour. I regard cheap labour as my starting point, given its centrality to our South African history of poverty and inequality. I attempt to engage the NDP in so far as it promises to deal with unemployment by 2030 - at the level of the metaphysics of its economics - its set of beliefs. This critical analysis is conducted from the perspective of a black theology of liberation. Black ethics, I argue, must be understood as critical ethics as it is grounded in the paradigm of liberation. ${ }^{1}$ Most recently, Daniel Finn's (2013) description of a 'Christian socialist critique' of capitalism generally captures my ethical approach.

In this work he traces a historical perspective of Christian views on economics and also provides an important juxtaposition of a 'Christian socialist critique' and a 'Christian libertarian view' (Finn 2013:5-10). The relationship of racism and economics (Cannon: 2011) is one aspect that shapes my approach. Indeed, as a black African, my use of African symbols suggests that I cannot limit my approach to a 'Christian socialist critique' only without affirming black African symbols in my critique of economics. I begin with a brief understanding of the black African ethics of work through the concept of 'home' or household, as a heuristic device. I then proceed to examine briefly the NDP - its grammar, interlocution and approach to employment issues. Essentially, I find economic growth as a condition of employment problematic, because my assessment of the NDP is supported by relevant ecumenical and liberation views on neoliberal economics.

1.For an argument about 'Black ethics as critical ethics' see Tsele (1994:125-137). There are other important works that are not in the text, whereas some in the text critique economics at a foundational level. Douglas Meeks's (1989) God the economist: The doctrine of God and political economy, and, in particular, the Accra Confession, broadly describes the ethical liberation approach that I assume in this work. 


\section{Umsebenzi: On the underside of the colonial and apartheid logic of work}

By analogy with the heuristic use of oikos, ${ }^{2}$ the concept of $i k h a y a$ [home] is employed as a heuristic device to illuminate the integral relationships of spheres and the conviviality of life in the black African worldview. Ikhaya is a heuristic device to aggregate the totality of life in a black African ethos. Umsebenzi, that is, work in ikhaya, cannot be understood without all the components of a home. Some of the important components of a home include people, faith, land, work, God and ancestors. Components could be understood as spheres, meaning that the components of ikhaya are spheres as we understand spheres in public life. ${ }^{3}$ All these different spheres are integral to a home, God being the highest transcendent order of a home, whilst ancestors harmonise the unity of a home.

This ethic is implied in one of the well-known sayings: umanyano nga mandla, meaning 'unity is strength' amongst black Africans. The type of unity implied in that saying, nonetheless, should be searched for in what has now become arguably an accepted view of how Africans view life and thus their cosmology. Not a single one of these components or spheres of a home can be understood to exist without considering the other. The fragmentation of one sphere disturbs the equanimity and harmony of the whole of ikhaya, the whole of public life and the African cosmos. Bediako (1995:95), for example, argues that human beings in the African setting live 'in a sacramental universe where there is no sharp dichotomy between the physical and the spiritual'.

Many other African scholars have made this point about the sacramental nature of life in the African value system. In this regard, work in African ethics should be understood as part of the sacramental whole of life, inseparable from all spheres of life and inseparable from God and ancestors too. I find Masoga's (2012) exposition of Setiloane's themes of African theology helpful:

The living strengthen their dead by offering them service (inkonzo - Nguni, tirelo - Tswana); the departed in turn exert a real vital influence on the living and on their destiny. The visible world is one with the invisible; there is no break between. Therefore, at any one time any community is more than the sum total of the physical elements that composes [sic] it. (p. 335)

Firstly, the relationship of a person with ancestors - motho or umntu to the ancestors - is important. Secondly, there is the community aspect in the African cosmos and, thirdly, the image of God. In the quotation above, Masoga is giving exposition to the communal aspect of the African worldview.

2.Some of the best examples of the use of the oikos concept are found in the writing of Everett (1988) and Meeks (1989). The concept has also gained currency in the ecumenical movement and in other parts of the world such as Korea, where there is an ostensible oikos movement (cf. also Vellem 2002).

3.One remembers how Jürgen Habermas $(1981 ; 1987)$ views public life, namely his tripartite division of politics, economics and lifeworld as distinct spheres but parts of the whole of public life. The components of an African home could similarly be used to differentiate spheres as parts of the whole public life and the cosmos be used to diffe
heuristically.
He explains that inkonzo, which is equivalent to our chosen word umsebenzi, is offered to the living dead, who in turn reciprocate by exerting a real vital influence on their destiny. There is no break between human beings and ancestors, hence this sacramental view of life. In other words, umsebenzi encapsulates a transcendental and immanent view of life. In Sotho and Nguni languages, the plural for the word Modimo or Thixo [God] is Badimo or Izithixo, literally meaning 'gods'.

Often used to designate ancestors, particularly in Sesotho, the word Badimo [gods], in the phrase I use in this work, 'God or gods', is a punctuation of the ethical import that I seek to make, both literally and heuristically, namely that work cannot be separated from all spheres of ikhaya [home], worse still from God or gods (Badimo). ${ }^{4}$ Masoga (2012) says:

Ancestors are 'the guardians of the morality' (Daryl Forde) of the group, community in family, tribe or nation. They discharge this responsibility with excellence and effect because they are Badimo, Va-dimu, Wa-zinu (Swahili) literally 'the people of Modimo (Divinity) and transmitters of Modimo's essence, energy, Vital Force'. (p. 334)

I understand what Masoga (2012) is doing in his translation of Badimo, Va-dimu, Wa-zinu above. He implies that ancestors are people of Modimo, a rendition that is in the genitive tense rather than a literalism. My literal translation is equally accurate. I interpret Badimo [gods] as a plural for Modimo [God] literally. I do so because it is not 'un-African' to say Motho ke Modimo 5 meaning that 'a human being is God'. If a human being can be expressed as God, then to do the same about ancestors, more so when, etymologically, God and ancestors share the same word, could even be far less of a problem, if there is any given that the realm of the ancestors is above that of human beings. The two renditions are also not mutually exclusive, because ancestors are human beings who are departed and thus can share in the same saying, Motho ke Modimo, [a human being is God]. There is a reason for this exposition.

The logical ethical question for me is: 'How much has been lost by black Africans during their encounter with the West in their understanding of work?" I view the history of cheap, docile and migrant labour in South Africa with this ethical prism. Cheap labour in South Africa was a form of modern slavery and slavery is work disintegrated from other spheres of a home and, indeed, without God or gods! Slavery is work without God or gods!

It is work in the absence both of the transcendental and immanent dimensions of life. It is work without the being of a black African person. It is work without the sacramental and communal relationship of a black African to the totality of life. It is ipso facto the dethronement of God, the 'Vital Force' the Imago Dei I and denial of being you find in the character of the slavery and cheap labour experienced by black Africans. Furthermore, the point has already been

4.I need to make a further point that my intention here is to apply my understanding of African ethics more than give an exposition.

5.Masoga (2012) himself acknowledges this in the same article on pages: 323-334. 
made that the word tshebeletso or tirelo shares the same root as the word mosebetsi [work] and is therefore quintessentially liturgical. Indeed, this is not an alien idea in the African setting, because rituals that are performed for ancestors are generally called mosebetsi or tirelo or umsebenzi. So this liturgical dimension-the spiritual dimension of work-is lost in the history of the encounter between the West and black Africans. There is simply no work without God or gods in the black African imagination, and colonialism destroyed this image. If one takes into account the fact that African ethics is anamnetic, always a liturgy of re-membering, re-establishing and re-constituting one with the totality of one's life, then the loss of umsebenzi and its signification must be deeply understood. It is sacramental; it is a narrative that articulates the constant renewal of a community, and truly liturgical (cf. Bujo 2011:56-57).

Terreblanche (2002) says:

In the quarter century between the discovery of gold and the adoption of the Land Act, South Africa experienced revolutionary changes in social, economic, and political relationships. The emerging capitalist nature of gold and agricultural production generated a fundamental change in the nature of the demandby white employers-for African labour. Both the gold mining companies and white farmers claimed that they could only operate profitably if enough cheap and docile African labour was available. (p. 256)

Cheap and docile black African labour since the late 1890s is at the heart of the social, economic and political relationships in South Africa today.

Terreblanche (2002) provides a historical account of the inequalities in South Africa and paints a vivid picture of the assault black Africans suffered at the hands of the whites, in both the mining and the agricultural sectors. There is no space for me to provide the details of the violent history within which cheap and docile labour was created. It is nonetheless a fact. Even before the discovery of gold and the grabbing of land through the Land Act of 1913, the seeds of the harrowing experience of the violent extraction of labour from black Africans were already sown. Jennifer Wenzel (2009) discusses the violence in the seven frontier wars that led to the defeat of the amaXhosa before the discovery of gold and diamonds in South Africa. She says, 'AmaXhosa faced drought, floods, crop blight, and land and cattle shortages in the 1850s' (Wenzel 2009:18). In this context, she goes on to say:

Grey's policies tied famine relief to labor contracts that pulled the amaXhosa away from their lands and chiefs, and he oversaw the passage of legislation that required "passes" to enter the Cape Colony for some Africans, but not others, on the basis of ethnicity. The cattle killing was not only a devastating event in the history of amaXhosa but also a seminal moment in the history of colonialism, segregation, and apartheid in southern Africa. (Wenzel 2009:19-20)

The disastrous circumstances of the amaXhosa, a beleaguered people after internecine frontier wars of dispossession in the Eastern Cape, became an opportunity for creating cheap labour. This devastating moment of the history of the amaXhosa is seminal to the history of colonialism, segregation and apartheid. One can even move backwards a little to unearth this history. If one takes into account the usurpation of African history by the West since 1492, as Sabelo NdlovuGatsheni (2013) argues, then one should appreciate the extent to which African values have been subjugated by the West. The entrapment of Africa in the colonial matrices of power throughout the Europeanisation of the world and thus the slave trade is a tale of terror that links economics to racial bigotry. Ndlovu-Gatsheni (2013:336) eloquently expresses this entrapment as manifest in the ubiquity of the West 'through its 'models of growth and development', the writing out of African people from the 'zone of being' into a 'zone of non-being' (ibid:338) and the uncritical embracing of 'modernist vocabularies and concepts' (ibid:342) in the quest for the liberation of Africans.

In this long history of African entrapment by the West, the loss of the understanding of the black African concept of umsebenzi [work], which is sacramental in nature, was violent and racist. This is what the picture of umsebenzi entails on the underside of colonial and apartheid regimes in our land. I venture to examine the promise of the NDP with this ethical perspective in mind.

\section{National Development Plan (NDP) and unemployment}

Terreblanche (2012) says this about the NDP:

The main targets of the Commission are to reduce the proportion of the people living below the level of R418 (at 2009 figures) from the current 39 per cent of the population to zero, and to reduce the unemployment rate from 27 per cent in 2011 to 6 per cent in 2030 by creating an additional eleven million jobs. If these targets and the other targets set by the Commission can be accomplished by 2030 it would be an excellent accomplishment. (p. 116).

These sentiments above set the tone for my engagement with the NDP text. What Terreblanche (2012) further says is even more vital for my argument:

But who is going to implement the policy measures that will be necessary in order to realise the hyper-optimistic targets set by the NDP? Who is going to equalize the unequal power relations, the unequal property distribution and the unequal opportunities that must be put right before the NDP targets can be attained. (p. 116)

There is no need to expand more on the questions Terreblanche (2012) poses above, save to say that power relations, property and opportunities that should be equalized, as he argues, are issues related to the ethical questions I have already raised. They cannot be postponed whilst unemployment is dealt with in South Africa. The NDP employment targets require the loss of power that black Africans suffered with the resultant inequalities that define our country to be restored before the targets are attained. 
Terreblanche (2012) says the targets are good, but add no value:

before the South African politico-economic system can become functional to serve the interests of the total population instead of the narrow class interests of the capitalists and political elite, as has been the case from 1886 until 1994, and over the past eighteen years. (p. 116)

The NDP executive summary document devotes close on 10 pages on the vision of a South Africa that might have been constructed by 2030. South Africa will have become 'a home where everybody feels free yet bounded to others; where everyone embraces their full potential' (NDP executive summary 2011:1). It is important to note that the opening lines of this vision employ the notion 'home', which is a heuristic device I have employed to explore an African understanding of the ethics of work. As a result, I immediately imagine an integration of all the components identified in the NDP for its success in creating this 'home'. Undoubtedly, there are other metaphors in the statement of the vision, such as the 'rainbow' (NDP executive summary 2011:12), which could also be pursued for an ethical engagement of the NDP.

The NDP purposes to 'eliminate poverty and reduce inequality by 2030' (NDP executive summary 2011: 14). It is quite fascinating that very early on in the document the NDP (executive summary 2011:14) cites a statement from the 'Reconstruction and Development Programme' (RDP) which places poverty as the first priority and, ipso facto, its elimination as a condition for the success of any democratic dispensation. At this very early juncture of the $\mathrm{NDP}$, one could assume, either rightly or wrongly, that the mediation of the Plan is centred on the poor. Indeed, the NDP clearly states that '... South Africa must translate political emancipation into economic well-being for all' (NDP executive summary 2011:14). The NDP then offers a background to the appointment of the National Planning Commission in May 2010 and, most importantly, refers to the Diagnostic Report released in June 2011 which identified 'nine primary challenges' in South Africa post- $1994{ }^{6}$

There is probably nothing we can fault in this diagnosis apart from stating candidly that there is nothing profoundly new about these primary challenges - not one of them could be unrelated to the crux of the struggle for liberation waged by the oppressed people of this land. ${ }^{7}$ Now, if these

6.These were: (1) Too few people work; (2) The quality of school education for black people is poor; (3) Infrastructure is poorly located, inadequate and undermaintained; (4) Spatial divides hobble inclusive development; (5) The economy is unsustainably resource intensive. (6) The public health system cannot meet demand or sustain quality; (7) Public services are uneven and often of poor quality; (8) Corruption levels are high; and (9) South Africa remains a divided society (NDP (8) Corruption levels are high,
executive summary 2011:15).

7.Let me make a note on a few of these problems so as to clarify what I mean by this. Employment in South Africa was racialised, cheap, docile and migratory. It is not just about unemployment, which has, indeed, become so high in the post-1994 South Africa, but a combination of these factors. Education and the Soweto uprisin in South Africa, or even the models that were adopted as far back as the times of Steward of Lovedale in South Africa, are equally not a new challenge that is devoid of racial, economic and cultural dimensions. The spatial divides or, better still, the colonial and apartheid geographies, the economics of racial enclaves, health, public colonial and apartheid geographies, the economics of racial enclaves, health, public service and corruption all constituted some of the key grievances that justified the struggle for liberation. So they are not new challenges, this must be emphasised. This is the language of the struggle. The approach to dealing with these challenges was also manifest in the different positions that were assumed by various strands in the struggle for liberation, either ideologically or tactically. What, then, informs the approach of the NDP amidst these latent approaches from the liberation struggle is more important than the diagnosis of these problems. challenges are not new, the manner in which the Planning Commission sets out to tackle them is crucial. In other words, the language of the NDP is good, the metaphors are good, even the diagnosis of the challenges is fairly good, but what is the 'grammar' of this language? Is it about the equalisation of power and ownership or an elitist dream feigned as a response to the restoration of work with transcendence, being, spirituality and harmony?

Let us move a little further. The NDP adopts a multidimensional approach and explicitly espouses a 'capabilities approach' for the transformation of the economy and society. This is arguably its 'grammar'. This obviously places Amartya Sen's theory (1999a; 1999b) of capabilities at the centre. (It is important to remark that one cannot read the emphasis on capabilities without Amartya Sen coming to mind.) Sen has argued that human beings should be enabled to achieve crucial 'functionings' in order to convert a capability into a function (Van Til 2008:85). In this manner, by espousing an approach that clearly seeks to emphasise capabilities (NDP executive summary 2011:17), the NDP makes it possible for us to engage its 'grammar' ethically now - the capability theory of economics and anthropology and for me, Amartya Sen comes to mind.

Briefly, capabilities theory entails that there are critical capabilities that are indispensable to transformation in an economy and a society. According to Van Til (2008), Sen's theory of capabilities challenges mainstream economic theory, which looks at poverty in terms of income and its assumptions about individuals' preferences that are deemed in mainstream economic theory to lead to personal well-being (Van Til 2008:86-87). Sen's theory of capabilities recognises the need for one to function in a community, the factors that impact on the functioning of individuals in order for a person's capabilities to function as human agency. I can explain this further by saying that the capability of a person must function in the transformation of an economy and society if human agency is related to the functions of the capabilities. Capabilities theory and agency are, therefore, related. Clearly, in dialogue with black ethics, and the loss of the sacramental view of work, umsebenzi, what the crucial functionings a black African person have lost in order to gain the capability to work is a crucial question. Employment and agency are more clearly related. The agency of a black African person under colonialism and apartheid is essentially a component in dealing with unemployment. I am not imposing this view on the NDP; these sentiments are triggered by its stated use of the capabilities theory. Employment must thus give the workers the capacity to function for the transformation of society and their liberation.

Unity, active citizenship, economic growth, capabilities of the people, the state and strong leadership are priority pillars of the Plan's success. I have identified the challenges that the NDP seeks to respond to and some of the theoretical assumptions that undergird its approach. This is how far I think we should go regarding what I have designated the 'grammar' of the NDP. Clearly, as we go on with this 
point, the question about the compatibility of 'language' and its 'grammar' is pivotal in democratic discourse. Are the theoretical assumptions of the NDP, its metaphysics, compatible with the language and the metaphors selected? Whose language? Whose metaphors and grammar? Let us keep this question in mind. I propose that we glance at chapter 3 of the 'National Development Plan: Vision 2030', the main document.

It is entitled: 'Economy and Employment. ${ }^{8}$ The NDP seems to suggest that economic growth is the central tenet, if not a prerequisite for dealing with unemployment in South Africa. The NDP proposes active labour market policies, especially for the youth. Accordingly, it is envisaged that 24 million people will be employed in 2030. What is termed a 'social compact' is uppermost in the actions that are required to support the goals of the plan. It is also encouraging to note that phrases such as 'full employment, decent work and sustainable livelihoods' are used (NDP executive summary 2011:90). The chapter nonetheless makes a strange statement about what it designates 'realistic salaries'. It seems to suggest that workers should not as a result of their lack of requisite skills demand high salaries that are unrealistic. I read this in this manner because it also combines this notion of 'realistic salaries' with labour bargaining. Labour relations and bargaining processes have immense implications for the relationship between employers and employees.

The overall tactical approach of the NDP is summed up in the assertion that all the aspects of the plan are conditional upon the achievement of the projections made in the document (NDP executive summary 2011:91). This in one way or another suggests that, according to the NDP, employment is related to all the aspects that are envisaged in the plan. But let us turn the question around to clarify the point I am making. If there is no economic growth as projected in the NDP, the problem of unemployment will certainly not be resolved, or the targets envisaged in the plan might not be attained. For this reason, one should be compelled to look closely at the tight choices the Commissioners make in the light of the three scenarios they paint in this chapter. The selected scenario on the basis of which the entire plan is projected requires a lot for its goals to be attained. For example, there is talk of reducing the cost of production. There are structural challenges that must be tackled. There will be a need to promote exports, a need to promote employment in labour intensive industries. There will be a need to give attention to the capacity of the government. Implied in this plan is that even leadership in South Africa has a negative impact on the creation of employment.

In my view, the NDP, whilst employing the language of decent work and sustainable livelihoods, spends more time on the economic tactics that seemingly become a sine qua non [an essential element or condition] for employment creation in South Africa, let alone the fact that $90 \%$ of the jobs envisaged in 2030 will be domestic and in small businesses,

8.1 do not intend to repeat what is in the document itself, but to move on the questions that come to mind reading this section of the NDP. if my reading is correct. That the success of employment creation must be dependent on all the tactics proposed in the plan is a bit worrisome. It points to the fragility of this promise. The metaphysics of economic growth therefore bears examination. But what do others say about the NDP before we evaluate its metaphysics?

\section{Public views on the NDP}

In the Business Times section of the Sunday Times of 24 November 2013, Ray Hartley raises an important question about what has become known as 'jobless growth' in South Africa. This notion signifies the growth of the economy which has not yielded much when it comes to employment creation. According to Hartley, some of the policies that were adopted in post-1994 South Africa account for this. The Labour Relations Act of 1995 is one such example, Hartley argues. He says:

It sought to award workers the 'victory' they had fought for during the struggle years when labour law favoured business. The problem is that the LRA went too far the other way, making the labour market 'inflexible', a way of saying that it made it so much harder for employers to manage and fire workers that they simply avoided hiring them in the first place (Hartley 2013:3).

To support his argument, Hartley (2013) appeals to a number of reports: the International Monetary Fund's report, Econometrix, the policy research organisation led by Neil Rankin at the University of the Witwatersrand, and Goldman Sachs. The motivation of this analysis by Ray Hartley seemingly is the fact that parliament has passed amendments that have made the Labour Relations Act even more inflexible. For this reason, Hartley argues, there will be more job shedding as a result of these amendments.

This is ostensibly lamentable, according to him, given the fact that:

The government itself has pointed out a need for greater labour market flexibility. It did so in its 1996 Growth Employment and Redistribution strategy, in its 2006 Accelerated and Shared Growth Initiative and in last year's National Development Plan. (Hartley 2013:3)

As is evident in the sentiments expressed by Hartley above, there has been a thread of this notion of market flexibility throughout the economic policy dispensation of our land since the demise of Apartheid: from Growth Employment and Redistribution (GEAR), Accelerated and Shared Growth Initiative (ASGISA) and the current NDP. In other words, this policy trajectory is not only similar in its commitment to economic growth, one could safely surmise, but also similar in so far as market flexibility - the lifting of restrictions on 'labour brokers' - is concerned, conditions apparently required for job creation. Yet there is no denying the fact that economic growth has not led to job creation in South Africa, at least not in so far as it has been portrayed as a panacea to the challenge of unemployment.

Let me hasten to say that it is a well-known fact that the Congress of South African Trade Unions (COSATU) and 
one of its affiliates, the National Union of Metal Workers (NUMSA), currently the largest of the affiliates in this federation, are diametrically opposed to the economic policy framework of the governing African National Congress (ANC). COSATU has been opposed to GEAR since 1996. NUMSA's Central Committee produced a document dubbed 'The national development plan: Mixed bag, downright neoliberal?' in 2013. One of the main points that the union movement is making is that there is no ideological difference between the NDP and the DA with regard to economic policy. Regarding economic growth, COSATU proposes a different approach altogether, where collective and public forms of economic ownership must be given credence if the history of dispossession is to be redressed. According to this view, some of the mining and petro-chemical industries must be controlled by the state in order for redistribution of power to be attained. The argument is that the NDP is not framed to enhance economic ownership and redistribution of wealth in South Africa.

Full employment, the union movement argues, must derive from a reconceptualisation of the Expanded Public Works Programme in such a way that it acts as an 'employerof-last-resort', (NUMSA 2013:24-25). Indeed, this view is diametrically opposed to the $\mathrm{ANC}^{\prime}$ s economic policies since 1996. This is symptomatic of a long ideological battle within the tripartite alliance of the ANC, the South African Communist Party and COSATU since the demise of apartheid. We now look briefly at the ecumenical views on the current global economic system.

I have essentially presented two important views about the public debates on this matter. One is that within the very trajectory of economic policies adopted since 1994 there has been jobless growth. The other view rejects the policy framework adopted since 1994 and argues from a different ideological perspective with a different set of beliefs. At this point, therefore, I need to introduce Terreblanche's (2012) views on the NDP as I opened up this discussion of the NDP with his views. Terreblache (2012:118) argues that the goals of the NDP might simply remain 'fairy-tale targets' if it fails to provide concrete answers to how these targets will be achieved. He argues that:

the ANC government and the ANC-controlled bureaucracy are far too weak and far too myopic - and also far too corrupt - to take the initiative in the planning of a developmental state, and they have not, in any case, the capacity to call the capitalist/ corporatist sector effectively to account. (Terreblache 2012:121)

Clearly, Terreblache (2012) is suspicious of the success of the NDP. I conclude this section by citing what he claims could be the problem:

When reading the NDP (and being overwhelmed by the multiplicity of targets set for 2030), one cannot but be suspicious. The members of the NPC ought to know that it is not possible to reach all the targets it has set by 2030. Why has the NPC formulated so many targets and with such sincerity if they cannot be realised in time? I suspect that the NDP is actually a carefully crafted ideological propaganda document. This version of ideological propaganda could be called the 'ideology of targetism'. (Terreblache 2012:122)

Jobless growth is still a problem after 20 years of democracy. This must surely mean that there is a problem at the foundation of the notion of economic growth.

But there is an alternative voice: since 1994, the unions have argued against having a conservative economic framework in South Africa. The NDP is now even dubbed a propagandist instrument for an ideology of targetism. I conclude this conversation with an ethical evaluation of the metaphysics of the current economic order.

\section{The myths of neoliberal economics}

A plan is always the best thing to have, no matter how bad it might be. That there is a plan to deal with our challenges in South Africa must be applauded. Nevertheless, the rupture of the sacramental view of work, is what this plan must respond to. It is important to observe that the NDP does not clearly engage the contestations around the notion of globalisation. Rebecca Peters identifies theories of globalisation that are dominant and also looks at the theories of globalisation that resist neoliberalism. In her critique of neoliberal globalisation she says:

The vision of the good life offered by neoliberalism is indeed attractive and highly sought after by many people around the globe. Individualism, prosperity, and freedom are three values that in and of themselves have a great deal of merit. The problem is that this particular vision of the good life imagines as its primary constituent that illusive Homo economicus we encountered earlier - an atomistic, male individual who exists outside of time and space, with no obligations to family or community that might impinge on his freedom to pursue prosperity through hard work. Unfortunately, as we have seen throughout this study, this idealized vision of life simply does not correspond to the reality of global economy or to the lives of the majority of the world's workers. (Peters 2004:175)

The charge that the NDP is located within the neoliberal framework of economics places its assumptions about work within the quandaries of the illusive homo economicus [economic human]. Dwight Hopkins (2001:8) is correct when he says '... globalization of monopoly finance capitalist culture is itself a religion'. This has also been punctuated by the ecumenical perspectives I suggest we now consider briefly.

There are two important documents that have shaped ecumenical discourse in relation to the dominant paradigm of economics in the past decade or so. The first is called, 'Alternative globalization addressing people and earth' (AGAPE ), put out by the World Council of Churches (WCC) and which was presented in the General Assembly of the WCC in Porto Alegre, Brazil in 2007. Initially launched in Harare, at the WCC Assembly in 1998, AGAPE underwent a process, according to Mshana and Peralta (2013:vii), that sought to respond to this question: 'How do we live our faith 
in the context of globalization?'). Importantly, through this process, the WCC, whilst distinguishing various forms of globalisation, has made it clear that global capitalism and its dominant neoliberal agenda is pernicious and threatening to life. According to Mshana and Peralta (2013:viii), the AGAPE call in Porto Alegre came 'at a time when the unfettered market too was virtually the image of God and when the role of governments to enforce regulations to protect public goods was severely weakened'.

The 'virtual image of god' is the most important point for us. Jung Mo Sung supports this point when he challenges the modernist model of anthropology; particularly what he says designates the 'secularization of myth' where religious language and secular language cease to be different. Jung (2011:253-254) says the problem is caused by an incorrect sense of incarnation where human beings now want to become God, 'the foundational myth of the modern West, underlying all other myths'. This distortion of the doctrine of the incarnation of God is at the root of the myths created by modernity, where a human being is ultimately deified, thus destroying the boundaries that pre-modern societies and indigenous civilisations such as the African one continue to impose.

In collaboration with the then World Alliance of Reformed Churches (WARC) (now the World Communion of Reformed Churches (WCRC), these ecumenical bodies, the WCC and the Council for World Mission (CWM) gave birth to what is called the Oikotree movement with the sole purpose of putting justice as a matter of faith. The Accra Confession that was adopted by the WARC in Accra, Ghana in 2004 is one such attempt at engaging the neoliberal parading from the point of view of faith.

In the Oikotree movement's statement, discussed in Johannesburg in 2013, these words are important for our purposes:

We reject the production of structural unemployment and precariousness of work that continues to reduce workers, particularly women, to modern slaves on the altars of capitalistic accumulation and the shrines of transnational industry. (Oikotree Global Forum 2013:vi)

The current dominant global economic model has usurped a place that belongs only to God. It is perpetuated as a virtual 'image of god' with myths that have distorted our selfunderstanding and limits as human beings. In this context, unemployment is created and produced structurally. As Carlos Larrea (2014) puts it:

The market mechanisms behind the process of global economic growth have not only deepened this growing exclusion, but they have also profoundly damaged the capacity of nature to sustain growth. (p. 5)

It has become common knowledge that: 'the poorest half of the world's people possesses barely 3.7 percent of its wealth, and the poorest 10 percent has access to barely one thousandth of the world's riches' (Larrea 2014:4). ${ }^{9}$

Brendan Peacock and Business Times staff, in the Sunday Times of 01 December 2013, argue that the richest 100 people in South Africa enjoy an amount of wealth that is equivalent to more than $6 \%$ of the gross domestic product (GDP) of South Africa. What I also find interesting in this article is the fact that the growth in salary averages is acknowledged, placed at $7.6 \%$, yet the authors say that 'salaries of the rich have soared' (Peacock 2013:1) and that the list of the 100 richest remains dominantly white and male (ibid:2). One person's salary (David Hathron's) is 'nearly 400 times that of an average South African' (ibid:1).

The chasm between the rich and the poor in many countries that have adopted an economic strategy of growth is morally unjustifiable. This chasm, according to the International Labour Organisation (ILO), 'has in turn impacted the employment relationship and the protections it traditionally offers' (2012:8). Even more worrisome is the second point that needs to be made: on average, only between $8 \%$ and $9 \%$ of wealth transfer could change the picture of poverty, or even eradicate it completely. About Ecuador, for example, Larrea (2014) concludes that:

it would be enough to transfer no more than 9 per cent of national income to the poor in order to eliminate poverty and 2 per cent to eliminate extreme poverty. (p. 11)

I argue that labour is central to the objectification of human dignity (Dussel 2003:43). In line with the ILO's agenda, employment should be placed at the heart of economic and social policies, especially for those who are unemployed (ILO 2012:32). As a category that is so intrinsically related to human dignity, work cannot be subsumed under any economic model or economic policy and this is a general thrust that one finds in Christian traditions of work and those of other religions. The liberation paradigm therefore proceeds from this understanding in its analysis of poverty (Dussel 2003:45). Poverty is not an accident. Umsebenzi as the flipside of colonialism and apartheid shows this vividly. Musto Marcello's (2008:8ff.) point that capital did not start the world from the beginning should always be remembered. The capitalist mode of production is not absolute, it is historical. Anything to the contrary is a myth.

\section{Conclusion}

Is it the intention of the NDP propaganda to maintain modern slavery through the ideology of targetism? Modern slavery is a service that honours a pernicious economic system that operates virtually as God's image. The black African ethics of work cannot accept that taxation alone

9.The logic of this argument is similar to what Rogate Mshana and Park Seong-Won have designated in the AGAPE process and the Accra Confession as the 'champagne
glass economy'. In this global reality of the distribution of the global wealth, $20 \%$ of the wealthiest enjoy $83 \%$ of the global wealth, $20 \%$ of the middle ladder enjoy of the wealthiest enjoy $83 \%$ of the global wealth, $20 \%$ of the middle ladder
only $11 \%$ of the global wealth, whereas $60 \%$ of the poorest of the world enjoy only $6 \%$ of the global wealth. There are different statistical values that express thes disparities, but the point is that the inequality of wealth distribution in the world is so enormous and shameful that the current economic global order is left to persist to our own peril, including the mutilation of the whole of creation. 
can address the injustice caused by the alienation of work from its sacramental relationship with the rest of life. From an African perspective, God, being and spirituality are components of work, umsebenzi in South Africa, that remain trapped in a logic whose history is the violation of the individual. The conditionality of the NDP is too tight to offer any hope of its success. It evokes the thoughts contained in Luke 18:25: 'Indeed, it is easier for a camel to go through the eye of the needle than for someone who is rich to enter the kingdom of God'. That is a matter of faith.

\section{Acknowledgements Competing interests}

The author declares that he has no financial or personal relationship(s) that may have inappropriately influenced him in writing this article.

\section{References}

Bediako, K., 1995, Christianity in Africa: The renewal of a non-Western world, Orbis, Maryknoll.

Bujo, B., 2011, Foundations of an African ethic: Beyond the universal claims of Western morality, Pauline Publications, Nairobi.

Cannon, K.G., 2011, 'Racism and economics: The perspective of Oliver C. Cox', in K.G. Cannon, E.M. Townes \& A.D. Sims (eds.), Womanist theological ethics: A reader pp. 3-21, Westminster John Knox Press, Louisville.

Dussel, E., 2003, Beyond philosophy, ethics, history, Marxism and liberation theology, Rowman and Littlefield Publishers, Oxford, New York.

Everett, W.J., 1988, God's federal republic: Reconstructing our governing symbol, Paulist, New York.

Finn, D., 2013, Christian economic ethics, Fortress Press, Minneapolis.

Habermas, J., 1981, The theory of communicative action: Reason and the rationalization of society, vol. 1, transl. T. McCarthy, Beacon, Boston.

Habermas, J., 1987, The theory of communicative action, Lifeworld and system: A critique of functionalist reason, vol. 2, transl. T. McCarthy, Beacon, Boston.

Hartley, R., 2013, 'The truth about jobless-growth', Sunday Times, Business Times, 24 November 2013, pp. 3-4.
Hopkins, D., 2001, 'The religion of globalization', in D. Hopkins, A.N. Lorentzen, E. Mendieta \& D. Batstone (eds.), Religions/globalizations: Theories and cases, pp. 7-32, Duke University Press, Duke.

International Labour Organisation, 2012, Convergences: Decent work and social justice in religious traditions: $A$ handbook, ILO Publications, Geneva.

Jung, M.S., 2011, 'Greed, desire and theology', Ecumenical Review 63(2), 251-262.

Larrea, C., 2014, 'Inequality, sustainability and the greed line: A conceptual and empirical approach', in R. Mshana \& A. Peralta (eds.), The greed line (Draft), pp. 1-28, WCC Publications, Geneva.

Marcello, M. (ed.), 2008, Karl Marx's Grundrisse, Routledge, London/New York.

Masoga, M.A., 2012, 'A critical dialogue with Gabriel Molehe Setiloane: The unfinished business of the African divinity question,' Studia Hisotiriae Ecclesiasticae XXXVIII, 323-344.

Mshana, R. \& Peralta, A. (eds.), 2013, Linking poverty, wealth and ecology, WCC Publications, Geneva.

Meeks, D., 1989, God the economist: The doctrine of god and political economy, Fortress, Minneapolis.

National Planning Commission, 2011, 'NDP executive summary', viewed n.d., from http://www.npconline.co.zaTerreblanche, S., 2002, A history of inequality in South Africa 1652 -2002, UKZN Press, Scottsville.

Ndlovu-Gatsheni, S., 2013, 'The entrapment of Africa within the global colonial matrices of power', Journal of Developing Societies 29(4), 351-353.

NUMSA, 2013, 'The national development plan: Mixed bag, downright neoliberal?', viewed n.d., from http://www.numsa.org.za/

Oikotree Global Forum, 2013, 'Global Kairos faith stance', Oikotree Movement, Johannesburg.

Peacock, B. \& Business Times staff, 2013, 'Shoprite boss tops rich list as South Africa's wealthiest get even wealthier', Sunday Times, 01 December, pp. 1-2.

Peters, R.T., 2004, In search of the good life: The ethics of globalization, Continuum, New York, London.

Sen, A., 1999a, Commodities and Capabilities, New York, Oxford

Sen, A., 1999b, Development as Freedom, Oxford, Oxford

Terreblanche, S., 2012, Lost in transformation: South Africa's search for a new future, KMM, Sandton.

Tsele, M., 1994, 'Ethics in black theology', in J. De Gruchy \& C. Villa-Vicencio (eds.), Doing ethics in context: South African perspectives, pp. 125-137, Orbis, Maryknoll.

Van Til, K., 2008, 'Human nature and human needs in recent economic theory', in D. Hicks \& M. Valeri (eds.), Global neighbors: Christian faith and moral obligation in today's economy, pp. 65-88, Wm. B. Eerdmans, Grand Rapids, Michigan.

Vellem, V., 2002, 'Ikhaya: The use of the African concept of home in public life with special reference to Kayamandi', Unpublished Master's dissertation, University of Cape Town.

Wenzel, J., 2009, Bulletproof, UKZN Press, Scottsville. 